\title{
Tematski rječnici kao nastavno sredstvo u p(r)oučavanju jezika
}

Sažetak: Svrha je ovog članka predstavljanje metodološkog statusa rječnika u procesu učenja / nastave drugih slavenskih jezika i određivanje osobitosti dvojezičnog edukativnog ukrajinsko-hrvatskog tematskog rječnika.

U razvoju nacionalne kulture te očuvanju i usavršavanju jezika određenog naroda važno mjesto pripada rječnicima. Tijekom tridesetogodišnjeg razdoblja postojanja neovisnih država Hrvatske i Ukrajine objavljena je tek neznatna količina hrvatskih i ukrajinskih leksikografskih izdanja koja bi se istovremeno odnosila i na hrvatski i na ukrajinski jezik. Važna uloga rječnika u učenju stranih jezika ne zahtijeva komentare, kao ni to da je ta činjenica općenito prihvaćena u metodama poučavanja, što znači da su rječnik i udžbenik neophodna sredstva u nastavnom procesu. Prilično dugu povijest ima i navođenje i grupiranje riječi u rječniku. Tradicionalan i najuobičajeniji u svjetskoj leksikografiji abecedni je redoslijed leksičkih jedinica. Alternativa abecednoj leksikografiji tematska su i ideografska leksikografija.

Ključne riječi: edukativni rječnik, tematski rječnik, sastavljanje rječnika, organizacija leksika, ukrajinsko-hrvatski rječnik

U razvoju nacionalne kulture te očuvanju i usavršavanju jezika određenog naroda važno mjesto pripada rječnicima. Odgovarajuća razina razvoja kulture opredjeljuje se, između ostalog, i stupnjem razvoja leksikografije. Stjecajem povijesnih okolnosti tiskana leksikografska produkcija pojavila se davno i gotovo istovremeno ${ }^{1}$ u Ukrajini i u Hrvatskoj.

\footnotetext{
${ }^{1}$ Prvo je takvo ukrajinsko izdanje crkvenoslavensko-ukrajinski rječnik L. Zizanija iz 1596., tiskan u Vilniusu pod nazivom Лексис, Сир-1ь Реченїл, ВькратьиПсьбран(ь)ньі и из слове(н)скаго язьїка на простьі(й)рускій діАле(к)ть истол(ь)кованьі (prvo izdanje) u kojem se 1061 crkvenoslavenska riječ prevodi ukrajinskim književnim jezikom druge polovice 16. st. Prvi hrvatski tiskani rječnik F. Vrančića objavljen je 1595. F. Vrančić je 5800
} 
Zanemarimo višestoljetni, ponekad težak, put razvoja leksikografije uovim zemljama, obratimo pozornost na suvremeno stanje razvoja ukrajinsko-hrvatske leksikografije, pa možemo konstatirati da je u tridesetogodišnjem razdoblju postojanja neovisnih država Hrvatske i Ukrajine tiskana tek neznatna količina hrvatskih i ukrajinskih leksikografskih izdanja koja bi se istovremeno odnosila i na hrvatski i na ukrajinski jezik. Donedavno nije bilo dvojezičnih rječnika koji su neophodni za proučavanje obaju jezika (znanstveno, umjetničko prevođenje i dr.), bez obzira na to što već više od dvadeset godina hrvatski jezik postoji kao studij na ukrajinskim sveučilištima, a ukrajinski pak na hrvatskim sveučilištima. ${ }^{2}$

Posljednjih su se godina u Ukrajini pojavili udžbenici i priručnici prilagođeni nastavi hrvatskog jezika, ${ }^{3}$ a objavljen je i Ukrajinsko-hrvatski tematski rječnik ${ }^{4}$ namijenjen studentima visokoškolskih ustanova. Krajem 2018. godine objavljen je i Ukrajinsko-hrvatski rječnik. ${ }^{5}$ Rječnik nastavlja niz ukrajinsko-slavenskih rječnika koji služe kao pomagala prilikom prevođenja i kojima je jezik na koji se prevodi - slavenski jezik, a u kojem se glavni leksički minimum ukrajinskog jezika prevodi ekvivalentima srodnog jezika. Posebnost njegova uređivanja odnosi se na zahtjeve za kratke dvojezične rječnike s obzirom na činjenicu da veliki dvojezični ukrajinsko-hrvatski rječnik još uvijek nije objavljen. U rječniku je zastupljen aktualan suvremeni leksik, kao i fraze koje se aktivno upotrebljavaju u različitim funkcionalnim stilovima standarda te su prikladne za raznovrsnu komunikaciju ukrajinskog i hrvatskog korisnika. U registru Ukrajinsko-hrvatskog rječnika nalazi se više od dvadeset pet tisuća riječi. Rječnik je dio univerzalnog sustava slavenske leksikografije Leksika-Slavika, a razradila ga je ekipa suradnika Ukra-

hrvatskih riječi uglavnom preuzeo s čakavskoga područja, ali i iz djela pisanih drugim hrvatskim narječjima, i preveo ih na pet europskih jezika: latinski, talijanski, njemački, dalmatinski tj. hrvatski i mađarski. Tako vidimo da i ukrajinska i hrvatska leksikografija imaju dugu tradiciju.

2 Studij kroatistike na ukrajinskim sveučilištima, i ukrajinistike - na hrvatskim, postoji više od dvadeset godina o čemu svjedoče i ovi zbornici: Ukrajinistika na sveučilištu u Zagrebu: 20 godina (Zagreb: FF, 2018) і Вісник Львівського університету. Серія філологічна. Хорватистика (Львів: ЛНУ ім. Івана Франка, 2018, Випуск 69).

${ }^{3}$ Udžbenici i priručnici hrvatskog jezika za Ukrajince: Людмила Васильєва і Дамір Пешорда, Хорватська мова для українців: підр. (Львів: ЛДУ ім. Ів. Франка, 2000); Людмила Васильєва і Дамір Пешорда, Хорватська мова: підр. (Львів: ЛНУ ім. Ів. Франка, 2007); Людмила Васильєва і Дамір Пешорда, Хорватська мова: 3б. Вправ (Львів: ЛНУ ім. Ів. Франка, 2007).

${ }^{4}$ Tematski rječnik: Людмила Васильєва, Богдан Сокіл і Ольга Ткачук, Українсько-хорватський тематичний словник (Львів: ЛНУ ім. Ів.Франка, 2016).

${ }^{5}$ Ukrajinsko-hrvatski rječnik: Людмила Васильєва, Ольга Ткачук і Володимир Чумак, Українсько-хорватський словник (Київ: Словники України, 2018). 
jinskog jezično-informacijskog fonda Nacionalne akademije znanosti Ukrajine, koji je omogućio realizaciju teoretskih postignuća znanstvenika te institucije uz opredjeljenje parametara leksikografskog sustava dvojezičnog slavenskog leksikona i stvaranje odgovarajuće leksikografske baze podataka. Statistički podaci računalne obrade sustava riječi ukrajinskog jezika pripomogli su formiranju registra Rječnika koji se pretežito sastoji od leksika opće uporabe s malobrojnim arhaizmima, vulgarizmima ili dijalektalnim leksikom koji danas čini dio aktivnog leksika standardnog jezika.

Poslije ovog kratkog uvoda treba najprije naglasiti važnost rječnika u učenju stranih jezika, što zapravo ne zahtijeva posebne komentare, kao ni to da je ta činjenica općenito prihvaćena u metodama poučavanja, što znači da je rječnik, kao i udžbenik, neophodno sredstvo u nastavnom procesu. Taj aspekt posebice je važan za proučavanje leksičkog sustava jezika. Ovdje bismo htjeli obratiti pozornost na dvije činjenice. Prvo, leksička razina zauzima središnje mjesto u jezičnom sustavu, a drugo, izdvajamo činjenicu da je jedno od glavnih obilježja leksičkog sustava vrlo mala mogućnost njegova strukturiranja: u leksičkom je sustavu znatno manje pravila. Ako je fonetske, morfološke i sintaktičke sustave jezika moguće prikazati čak i u početnom stupnju p(r)oučavanja jezika, leksički sustav gotovo je nemoguće prikazati zbog mnoštva različitih područja ljudske djelatnosti koja obično u takvim udžbenicima nisu zastupljena jer se u njima naglasak stavlja na teme koje su ograničene uglavnom na leksik opće uporabe. Smatramo da se taj nedostatak može nadoknaditi upotrebom, tematskog rječnika. Upravo to ističe posebnost edukativnih rječnika.

Osim toga, rječnici koji su namijenjeni nastavnom procesu ubrajaju se u sredstva koja se mogu najprikladnije spojiti s komunikacijskim metodama za $\mathrm{p}(\mathrm{r})$ oučavanje jezika jer pružaju mogućnost povezivanja rada na konverzaciji i na gramatičkom sustavu jezika. Drugim riječima, specifičnost tih rječnika može osigurati koegzistenciju sustavnog opisivanja posebnog jezičnog (leksičkog) podsustava ili njegovih fragmenata s orijentacijom na vježbanje različitih vrsta govornih aktivnosti: receptivnih (primanje informacije), produktivnih (govorenje, pisanje) i receptivno-produktivnih (komunikacija). Polazeći od toga, u ovome članku želimo obratiti posebnu pozornost na rječnike, pretežito namijenjene nastavi jezika, kao i ukratko predstaviti načela sastavljanja rječnika toga tipa polazeći od komunikativnosti korisnika u razgovoru na hrvatskom / ukrajinskom jeziku u nastavnom procesu, prijevodu, komunikaciji s govornicima navedenih jezika itd. 
Suvremeni su rječnici svojevrstan skup lingvokulturnih i sociolingvalnih jedinica, riječi i skupova riječi koji imaju sociokulturnu informaciju, kao i kulturne uvjetne znakove koji rukovode komunikativnim načinom djelovanja govornika određenih jezika. Prema mišljenju ukrajinskog leksikografa V. V. Dubičinskog, rječnik nije samo proizvod, nego i „smjer ideologije društva“ jer izbor definicije, oblika, područja uporabe jezičnih jedinica ovisi o ideološkim i kulturnim zahtjevima društva. Znanstvenik naziva rječnik „zrcalom kulture“ u kojem se društveni odnosi raznovrsno reflektiraju. ${ }^{6}$

Proučavanje sustavne organizacije leksika pokazuje da on nije jasno određen sustav jedinica. Čine ga podsustavi: raspoređivanje / distribucija riječi prema hipero-hiponimijskim hijerarhijama, tematskim i leksičko-semantičkim skupinama, sinonimskim redovima i antonimskim parovima, modeliranje leksika prema semantičkom polju, tvorbenim gnijezdima, učenju leksičkih jedinica u smislu njihove višeznačnosti / polisemije, što odražava određeni aspekt leksičkog sustava, ali ne pokriva taj sustav kao jedinstvenu cjelinu. U idealnom slučaju odgovarajući leksikografski opis trebao bi biti usmjeren na stvaranje opće slike leksičkog sustava sintezom raznih informacija o sustavnim vezama koje postoje među elementima i unutar tih elemenata. Dakle, svaku leksičku jedinicu ne treba prikazati izolirano, već u različitim vezama i odnosima s drugim jedinicama.

Problem navođenja i grupiranja riječi u rječniku ima prilično dugu povijest. To su pitanje prvi postavili filozofi. Naprimjer, G. Leibniz je početkom 18. stoljeća razmišljao kako pozicionirati jedinice rječničkog registra - abecednim redom, ,prema prirodi riječi“ ili prema „klasifikaciji pojmova“. Taj je filozof smatrao da je za „civilnu uporabu“ prikladno grupirati riječi po abecednom redu, dok ih je za ,filozofsko razumijevanje“ prikladno navoditi ,prema idejama“.7 U tim argumentima Leibniza nailazimo na proturječnost dvaju temeljnih leksikografskih načela: načela praktičnosti koje zastupaju abecedni rječnici i znanstvenog principa, uvjetovanog željom za razumijevanjem međusobnog djelovanja riječi te prikazivanjem tog djelovanja leksikografskim metodama (na tom principu temelje se tematski i ideografski rječnici).

Rasprave o tom pitanju na neko se vrijeme obustavljaju, a zatim se opet ponavljaju s obnovljenom snagom. I to je uzrok što danas nema

\footnotetext{
${ }_{6}^{6}$ Владимир Дубичинский, Теоретическая и практическая лексикография (Вена; Харьков: Харьк. лексикограф. о-во, 1998), 19.

${ }^{7}$ Cit. prema: Рубен А. Будагов, Толковые словари в начиональной культуре народов (Москва: Изд-во МГУ, 1989), 36.
} 
jednoznačnog rješenja ovoga problema. Pristalice abecednih, tematskih i ideografskih rječnika navode uvjerljive dokaze u vezi s prednošću njihovih pogleda na taj problem. Usporedit ćemo neke.

Tradicionalan i najuobičajeniji u svjetskoj leksikografiji abecedni je redoslijed leksičkih jedinica. On je uvijek bio u središtu pozornosti istraživača. Međutim, na periferiji njihove pozornosti dugo je ostajao tematski princip organizacije leksikona u rječniku. Treba obratiti pozornost na to da je kritika abecednog načina raspoređivanja leksičkih jedinica u mnogim slučajevima opravdana. Još je 60 -ih godina 20. stoljeća ruski znanstvenik J. D. Apresjan ukazao na lingvističku neprikladnost tradicionalnog abecednog načina raspoređivanja riječi jer „raspored riječi po abecednom redu, koji služi za praktične potrebe korisnika leksikografske produkcije, nije, naravno, znanstveno argumentiran“" Istu misao je ranije iznio $\mathrm{H}$. Casares, koji vjeruje da abecedni princip u rječniku nije ništa drugo nego „legitimiziran [u njemu - Lj. V.] poremećaj“ jer se u susjedstvu nalaze riječi koje uopće nisu vezane za svoj sadržaj. ${ }^{9}$ Osamdesetih godina, istraživači H. Jackson ${ }^{10}$ i T. McArthur ${ }^{11}$, govorili su o ,proizvoljnoj“ raspodjeli jedinica u abecednom rječniku, a T. McArthur napisao je da abecedni rječnik ne stvara generalizirajuću sliku vokabulara i ne odražava međusobno djelovanje njegovih elemenata. Kao rezultat takve interpretacije leksikon jezika nije podsustav, već zbirka uzajamno nepovezanih jedinica.

Alternativa abecednoj leksikografiji tematska su i ideografska leksikografija. Pristalice tematskog principa sastavljanja rječnika temelje svoju argumentaciju na nekim ključnim čimbenicima.

Prvo, svaka konceptualna shema, koja je izrađena racionalno, mnogo je bliža stvarnosti i organizaciji mentalnog leksikona nego bilo koja abecedna shema: što se događa u našoj svijesti kada sređujemo misli ili tražimo za nas neophodne riječi, to se ne zbiva po abecednom redu. ${ }^{12}$

Drugo, postoji određeno slaganje u pogledima predstavnika klasičnog, kršćanskog ili racionalnog svjetonazora u pogledu primarnih kategorija koje su temeljne u sistematizaciji čovjekove sredine, a zbiva

\footnotetext{
${ }^{8}$ Юрий Д. Апресян, Экспериментальное исследование семантики русского глагола (Москва: Наука, 1967), 16.

9 Хулио Касарес, Введение в современную лексикографию (Москва: Изд-во иностр. лит., 1958), 7.

${ }^{10}$ Howard Jackson, Words and their meaning (London, New York: Longman, 1988), 208.

${ }^{11}$ Tom McArthur, Worlds of reference: Lexicography, learning and language from the clay tablet to the computer (Cambridge etc.: Cambridge univ. Press, 1986), 147.

${ }_{12}$ McArthur, Worlds of reference: Lexicography, learning and language from the clay tablet to the computer, 123.
} 
se u procesu kognitivnih aktivnosti ljudi. „Konceptualne sheme, koje se razlikuju jedna od druge ovisno o osobi sastavljača, vremenu i mjestu sastavljanja, imaju ipak već važnu tematsku jezgru koja, čak i ako nije univerzalna, i dalje ukazuje na zajedničke interese jezičnih skupina u tematskoj leksikografskoj tradiciji.“13

Treće, tematski, ideografski, ideološki, analoški rječnici u kojima se leksikografske jedinice objedinjuju u skupine na osnovi asocijacija i veza razumljivih korisniku, pružaju mu mogućnost za bolje razumijevanje suštine jezičnog sustava u cjelini, a posebice njegova leksičkog sMeđutim, tematski i ideografski rječnici nisu bez nedostataka. Konkretno, još uvijek nije riješen problem navođenja polisemičkih jedinica. Različita značenja višeznačne riječi najčešće su vezana za različita semantička polja, što onemogućuje cjelovit prikaz unutarnje strukture. Semantička struktura riječi treba se raščlanjivati na odvojena značenja koja se navode u različitim dijelovima rječnika, a sustav uputa (pozivanja) komplicira rad s rječnikom i u većini slučajeva ipak ne oslikava pun opseg opisa višeznačnih riječi. Osim toga, tematsko i ideografsko modeliranje leksičkog podsustava umnogome je subjektivno jer se temelji na određenoj shemi koju nude sastavljači rječnika.

Ipak, proučavanje riječi po određenim temama ima mnogo veći učinak od proučavanja pojedinih, međusobno nepovezanih riječi. Dakle, tematski rječnik vrijedan je priručnik. Pa ako je na prvome mjestu edukativna uloga rječnika, tematske rječnike s periferije leksikografskih proučavanja potrebno je premjestiti u središte pozornosti lingvista. Glavna je značajka tematskog rječnika raspoređivanje leksika određenog jezika po temama s osvrtom na nastavno usmjeravanje. Takav rječnik, prije svega dvojezični, navodi tematski spojen leksik jednog jezika sredstvima drugog jezika. Tematski rječnik, ovisno o namjeri sastavljača, može imati različit opseg: veliki rječnik, primjerice, uključuje maksimalnu količinu leksičkih jedinica određenog jezika, a minimum je onaj u kojem je naveden leksik opće uporabe. Osim toga, tematski je rječnik rječnik aktivnog tipa jer sadrži građu namijenjenu komunikaciji i istovremeno osigurava proučavanje razgovornog leksika. Koristeći se takvim rječnikom, istovremeno proučavamo govorni jezik. Tematski raspored riječi omogućuje njihovo sustavno proučavanje i pridonosi boljem usvajanju. Većina tematskih rječnika ne pruža detaljne informacije s područja gramatike jer tematski su rječnici namijenjeni korisnicima

${ }^{13}$ Tom McArthur, „Thematic lexicography," $\mathrm{u}$ The history of lexicography: Papers from the Dictionary research centre seminar at Exeter, March 1986., ur. R. R. K. Hartmann (Amsterdam, Philadelphia: Benjamins, 1986), 161. 
koji već imaju barem minimalnu gramatičku vještinu u jeziku koji će detaljnije proučavati. Iz navedenog proizlazi određena količina različitih tematskih rječnika, leksički minimum - rječnici velikog opsega; tiskani - računalni rječnici; jednojezični - dvojezični (ili višejezični) rječnici, rječnici sastavljeni raspoređivanjem riječi po tematskim skupinama; rječnici sastavljeni prema jezičnim razinama predstavljenim za obradu u rječniku; ilustrirani - rječnici bez ilustracija.

U suvremenoj leksikografiji prilično je čest tip tematskog rječnika dvojezični tematski rječnik namijenjen nastavi koji navodi, kao što smo već prije naveli, tematski grupiran leksik jednog jezika odgovarajućim riječima drugog jezika. Prvi takav rječnik u slavenskoj leksikografiji bio je rusko-bugarski tematski rječnik. ${ }^{14}$ Među poznatim novijim leksikografskim radovima te vrste nalaze se ukrajinsko-poljski tematski rječnici ${ }^{15}$ i druge publikacije. Međutim, postoje jednojezični tematski rječnici namijenjeni izvornim govornicima jezika, npr. Систематски речник српскохрватскога језика ${ }^{16}$ koji sadrži, kao što navode autori, građu raspoređenu u četiri tisuće tematskih poglavlja (drugo dopunjeno izdanje, prvo izdanje rječnika iz 1940. godine).

Primjer takvog tematskog rječnika ilustrirani je tematski rječnik u kojem je značenje riječi prikazano slikom. Međutim, taj pristup navođenja jedinica u rječniku ograničava izbor leksičkog materijala jer ondje uopće nema mogućnosti za navođenje apstraktnih pojmova. Ipak, slike su dobar način predočenja, što u nastavi i p(r)oučavanju stranog jezika svakako daje pozitivan rezultat; postojanje izravne veze između predmeta i njegove slike stimulira razvoj kreativnog mišljenja korisnika, tako da je ta vrsta rječnika iznimno korisna za učenje konkretnog leksika, osobito u početnoj fazi p(r)oučavanja stranih jezika. Kao primjer možemo navesti rječnik slovačkog jezika u slikama: Obrázkový slovnik slovenčiny. ${ }^{17}$

Budući da je u nastavi stranih jezika tematski princip p(r)oučavanja leksika temeljan, onda i dijelovi bilo kojeg priručnika ili udžbenika nisu ništa drugo već tematski usmjerena skupina leksičke građe. Kada

\footnotetext{
${ }^{14}$ Кирил Бабов и Ангел Въргулев, Тематичен руско-български речник (София: Народна просвета, 1961).

15 Януш Pirep i Орися Демська-Кульчицька, Украӥнсько-польський тематичний словник (Львів: Видавництво УКУ, 2007); Iryna Kononenko, Stownik tematyczny polsko-ukraiński (Warszawa: Wydawnictwo Naukowe PWN, 2010).

${ }^{16}$ Ранко Јовановић и Лаза Атанацковић, Систематски речник српскохрватскога језика (Нови Сад: Матица српска, 1980).

${ }^{17}$ Ol'ga Škvareninova, Obrázkový slovník slovenčiny (Bratislava: Slovenské pedagogické nakladatel'stvo, 1997).
} 
govorimo o lingvo-kulturološkom temelju tematskog principa u proučavanju leksika, treba uzeti u obzir pojam određenog područja ili tematske grupe. Leksikografija nudi nekoliko opcija u vezi s raspoređivanjem leksičke građe po tematskim odjeljcima i pododjeljcima. Najčešće su riječi u odjeljcima i skupinama raspoređene bez upotrebljavanja određenih principa ili shema, tj. asocijativno, kada prethodna riječ kao da „traži“ da se navede sljedeća, otkrivajući temu ili podtemu odjeljka. Leksičku građu moguće je rasporediti i po abecednom redu, ali ponekad to može biti štetno za suštinu tematskog rječnika. To se događa u tematskim rječnicima namijenjenima nastavi, a autorima se često nameće odstupanje od tog načela navođenja riječi, koje se povezuju asocijativno. Postoji mogućnost raspoređivanja građe prema vrstama riječi (ideju raspoređivanja riječi u tematskim odjeljcima/cjelinama predložio je P. M. Roget u rječniku Tezaurus engleskih riječi i izraza $1852 .{ }^{18}$ Taj su princip primjenjivali autori sastavljajući rječnike: Тематичен-руско-български речник ${ }^{19}$ i Stownik tematyczny języka niemieckiego ${ }^{20}$.

Tematski princip organizacije leksičke građe primijenjuje se ne samo za navođenje leksika nego, primjerice, i za navođenje izraza, fraza, pa čak i rečenica u frazeološkim rječnicima. Tematska podjela frazeologizama na skupine otkriva njihov sustavni karakter, omogućuje prilaženje tom problemu globalno, prikazuje frazeološke varijante u određenoj značenjskoj skupini. Takav je Slovnik české frazeologie a idiomatiky ${ }^{21}$ koji se razlikuje od drugih frazeoloških tematskih rječnika raspoređivanjem građe (frazemi, koji su objedinjeni određenim općim značenjem, grupiraju se u veće tematske cjeline), a također dovoljno sličan njemu prema organizaciji građe je Словарь образных выражений русского языка, jednojezični tematski frazeološki rječnik koji pridonosi svladavanju građe pomoću primjera uporabe frazeologizama u govoru. ${ }^{22} \mathrm{Ti}$ su rječnici jednojezični i, iako imaju cilj sistematizirati i objasniti značenje određenih frazema jednog jezika, ipak se mogu upotrebljavati u nastavi stranog jezika na višim stupnjevima njegova $\mathrm{p}(\mathrm{r})$ oučavanja. Međutim,

\footnotetext{
${ }_{18}$ Peter Mark Roget, Thesaurus of English words and phrases classified so as to facilitate the expression of ideas and assist in literary composition (London, 1852).

19 Vidjeti o tome: Оксана Костюшко, „Тематичні словники у сучасній слов'янській лексикографії,“ Проблеми слов'янознавства, br. 53 (2003): 271-280.

${ }^{20}$ Grażyna Hatała i Małgorzata Bielicka, Stownik tematyczny języka niemieckiego (Zielona Gora: Kanion, 1996).

${ }^{21}$ František Čermak, Jiří Hronek, Jaroslav Machač a kol., Slovník české frazeologie a idiomatiky. D. 1-4 (Prag: Academia, 1983-1994).

22 Вероника Н. Телия, Словарь образных выражений русского языка (Москва: Отечество, 1995).
} 
tematski princip javlja se u proučavanju frazeologije $u$ dvojezičnim rječnicima, stoga što organizacija građe na određenu temu usmjerava korisnika na sustavno proučavajne frazeološkog blaga određenog jezika. Tako je npr. sastavljen Русско-болгарский тематический словарь фразеологизмов ${ }^{23}$, dvojezični tematski frazeološki rječnik.

Tematski princip klasifikacije građe, kao što vidimo, prihvatljiv je i racionalan za proučavanje različitih razina leksičkog sustava određenog jezika. Upravo zato smatramo da se suvremena leksikografija mora razvijati u tom smjeru, dopunjujući ga novim pristupima. Po našem mišljenju, takvi su rječnici od posebnog značaja za nastavu drugih slavenskih jezika. Polazeći od toga, na Filološkom fakultetu Sveučilišta Ivana Franka u Lavovu pristupili smo sastavljanju značajnih tematskih rječnika namijenjenih nastavi, u prvome redu studentima našega sveučilišta.

Ukrajinsko-hrvatski tematski rječnik prvenstveno je namijenjen studentima sveučilišta i visokih škola, srednjoškolcima, studentima različitih jezičnih tečajeva, ali može biti koristan i za samostalno proučavanje ukrajinskog i hrvatskog jezika svima onima koje ti jezici zanimaju, kao i turistima. Osnovna je svrha rječnika pridonijeti obradi konkretnih tema važnih za svakodnevnu komunikaciju, a djelomice i tema vezanih za opće probleme stručne komunikacije. Rječnik ima cilj pripomoći konverzaciji u različitim područjima. Građa rječnika uključuje najvažnija područja ljudskog života. U rječniku ima leksika vezanog za najvažnije pojmove iz svakodnevice, obrazovanja, znanosti, uključujući i računalne tehnologije, zemljopis, egzaktne, prirodne i humanističke znanosti. Posebna je pažnja posvećena razgovornom leksiku.

Treba napomenuti da u Ukrajini tada nije bilo nijednog dvojezičnog ukrajinsko-hrvatskog rječnika, pa smo uzimali u obzir zahtjeve za sastavljanje kratkih dvojezičnih rječnika drugih jezika. Koristili smo se svim mogućim jednojezičnim rječnicima ukrajinskog i hrvatskog jezika, kao i elektronskom verzijom rječnika Словники Украӥни Instituta jezično-informacijskih istraživanja. ${ }^{24}$ Taj je rječnik bio prvi pokušaj ukrajinsko-hrvatske dvojezične leksikografije, koji je tiskan u Ukrajini, te smo uvjereni da je koristan svima koji se tim jezicima bave.

Registar riječi u rječniku sastavljen je na ukrajinskom jeziku prema tematskom načelu. U određenim podgrupama riječi su naznačene abecednim redom.

\footnotetext{
${ }^{23}$ Сергей Влахов, Русско-болгарский тематический словарь фразеологизмов (В. Търново: Издателски центр, 1994).

${ }^{24}$ Словники України. Версія 1.04.2004 (Київ: Національна академія наук України, Інститут мовно-інформаційних досліджень, 2004). На диску.
} 
Došli smo do zaključka da je minimalna jedinica tematskog rječnika leksičko-semantička varijanta višeznačne riječi. Česti su slučajevi kada riječ ima više značenja koja su prilično udaljena jedno od drugog, a dio su nekoliko tematskih skupina, ustvari, ponekad su to leksičko-semantičke varijacije koje se koriste u različitim područjima, uključujući i svakodnevnu komunikaciju. Npr. leksem tijelo (tijelo općenito) pripada tematskoj skupini Čovjek, ali i tematskoj podskupini Tekućine $i$ čvrste tvari, koja je dio skupine Fizika itd.

Riječi su unutar pojedine skupine vokabulara po abecednom redu, izuzimanja i odstupanja od ovog principa pojavljuju se u navođenju riječi vezanih asocijativno. Naprimjer, sadržajna skupina Mehanika fluida, ili podskupina Dani u tjednu, ima(ju) takav poredak riječi:

$\begin{array}{ll}\text { Тіло } & \text { Tijelo } \\ \text { аморфне } ~ & \text { amorfno } \\ \text { анізотропне } ~ & \text { anizotropno } ~ \\ \text { ізотропне } ~ & \text { izotropno } \\ \text { статика } & \text { statika } \\ \text { динаміка } & \text { dinamika } \\ \text { рух ідеальної рідини } & \text { gibanje idea } \\ \text { рух в'язкої рідини } & \text { gibanje viskozr } \\ \text { тертя } & \text { trenje } \\ & \\ \text { понеділок } & \text { ponedjeljak } \\ \text { вівторок } & \text { utorak } \\ \text { середа } & \text { srijeda } \\ \text { четвер } & \text { četvrtak } \\ \text { п’ятниця } & \text { petak } \\ \text { субота } & \text { subota } \\ \text { суботній } & \text { subotnji } \\ \text { неділя } & \text { nedjelja } \\ \text { недільний } & \text { nedjeljni } \\ \text { день } & \text { dan } \\ \text { тиждень } & \text { tjedan }\end{array}$

Kod određivanja strukture rječnika vodilo se računa o ukrajinskim i hrvatskim korisnicima. Rječnik ima vrlo jednostavnu strukturu, nema fusnota, materijal je stavljen u dvije kolone s naslovima i podnaslovima u skladu s određenim područjima leksika koja su navedena u sadržaju. Elektronička verzija omogućuje da se određena riječ, s odgovarajućim leksičkim okruženjem, brzo pronađe. Većina tema završava glagolsko- 
-imenskim sintagmama s odgovarajućom rekcijom za jezičnu normu. Navođenje rekcije omogućuje pravilnost govora u praksi. Sastavljajući rječnik autori su uzimali u obzir važne jezične posebnosti Ukrajinaca i Hrvata. Ovo posebno zorno predočuju netradicionalne rubrike za takve rječnike, navođenje zemljopisnih naziva, a također i naziva stanovnika ukrajinskih i hrvatskih gradova. Tog nazivlja obično nema čak ni u solidnim rječnicima.

$\begin{array}{ll}\text { Донецьк } & \text { Doneck } \\ \text { донеччанин } & \text { Donečanin } \\ \text { донеччанка } & \text { Donečanka } \\ \text { Осієк } & \text { Osijek } \\ \text { осієчанин } & \text { Osječanin } \\ \text { оієчанка } & \text { Osječanka } \\ \text { осієчани } & \text { Osječani }\end{array}$

Osim toga, građa rječnika, koji sadrži najčešće korišten leksik iz specijalnih područja, može biti prikladna za prevođenje ukrajinskih i hrvatskih računalnih tekstova.

Zaključujući ovaj članak, treba još jednom naglasiti učinkovitost leksikografije, posebice tematske, u učenju stranog jezika. Osim toga, važno je da je danas problem nastajanja ukrajinsko-slavenskih rječnika aktualan - posebice kada je drugi dio rječnika neki južnoslavenski jezik - jer se takav rječnik može upotrebljavati kao običan dvojezični rječnik, ali i kao rječnik namijenjen nastavi određenog jezika, što će pridonijeti, nadamo se, razvoju ukrajinsko-slavenske leksikografije za nastavni proces, razvoju leksikografije općenito, a bit će od važnosti i za druge jezike, npr. zapadnoslavenske i istočnoslavenske.

\section{Literatura}

Апресян, Юрий Д. Экспериментальное исследование семантики русского глагола. Москва: Наука, 1967.

Бабов, Кирил, и Ангел Въргулев. Тематичен руско-български речник. София: Народна просвета, 1961.

Будагов, Рубен. А. Толковые словари в национальной культуре народов. Москва: Изд-во МГУ, 1989.

Влахов, Сергей. Русско-болгарский тематический словарь фразеологизмов. В. Търново: Издателски центр, 1994.

Дубичинский, Владимир В. Теоретическая и практическая лексикография.

Вена; Харьков: Харьк. лексикограф. о-во, 1998. 
Јовановић, Ранко, и Лаза Атанацковић. Систематски речник српскохрватскога језика. Нови Сад: Матица српска, 1980.

Касарес, Хулио. Введение в современную лексикографию. Москва: Изд-во иностр. лит., 1958.

Костюшко, Оксана. „Тематичні словники у сучасній слов’янській лексикографії““ Проблеми слов'янознавства, br. 53 (2003): 271-280.

Рігер, Януш, і Орися Демська-Кульчицька. Украйнсько-польський тематичний словник. Львів: Видавництво УКУ, 2007.

Словники України. Версія 1.04.2004. Київ: Національна академія наук України, Інститут мовно-інформаційних досліджень, 2004. На диску.

Телия, Вероника Н. Словарь образных выражений русского языка. Москва: Отечество, 1995.

Čermak, František, Jiří Hronek, Jaroslav Machač a kol. Slovník české frazeologie a idiomatiky. D.1-4. Praha: Academia, 1983-1994.

Hatała, Grażyna, i Małgorzata Bielicka. Słownik tematyczny języka niemieckiego. Zielona Góra: Kanion, 1996.

Jackson, Howard. Words and their meaning. London, New York: Longman, 1988.

Kononenko, Iryna. Słownik tematyczny polsko-ukraiński. Warszawa: Wydawnictwo Naukowe PWN, 2010.

McArthur, Tom. Worlds of reference: Lexicography, learning and language from the clay tablet to the computer. Cambridge etc.: Cambridge univ. Press, 1986.

McArthur, Tom. „Thematic lexicography““ The history of lexicography: Papers from the Dictionary research centre seminar at Exeter, March 1986., ur. R. R. K. Hartmann, 157-166. Amsterdam, Philadelphia: Benjamins, 1986.

Roget, Peter Mark. Thesaurus of English words and phrases classified so as to facilitate the expression of ideas and assist in literary composition. London, 1852.

Škvareninova, Ol'ga. Obrázkový slovník slovenčiny. Bratislava: Slovenské pedagogické nakladatel'stvo, 1997.

\section{Thematic Dictionaries in Language Teaching}

Summary: The purpose of this article is to present the methodological status of the dictionary in the process of learning/teaching other Slavic languages and to determine the features of the bilingual thematic educational Ukrainian-Croatian dictionary.

Dictionaries play an important role in the development of national culture and in the supporting and improving a particular native language. During the thirty-year period of independence both Croatia and Ukraine can boast only a small amount of Croatian and Ukrainian lexicographic editions that could simultaneously apply to Croatian and Ukrainian. The important role of vocabulary in learning a foreign language does not require any comments. In fact it is generally accepted in teaching methods, which means that dictionary, as well as textbook, are necessa- 
ry means in the teaching process. Noting and grouping words in dictionary also has a fairly long history. The alphabetical order of lexical units is traditional and commonly accepted in the world lexicography. Hence, thematic and ideographic lexicography are supposed to be alternatives to alphabetic lexicography.

Keywords: educational dictionary, thematic dictionary, dictionary compilation, vocabulary organization, Ukrainian-Croatian dictionary 